\title{
Gratifications of Facebook: A Literature Review
}

\author{
Rahul Gadekar, MICA, India \\ Pradeep Krishnatray, Johns Hopkins University, India
}

\begin{abstract}
This study reviews the articles related to gratifications of Facebook use. An analysis of 20 gratifications studies states that mostly target audience of these studies is youth, especially students. The analysis concludes that these studies relied on the literature to develop the gratifications scale. Some of the gratifications factors identified are same and some of them differ. It was observed that there is an overlap among some gratifications factors due to similarities and differences in the operationalization of the gratification factors. Study highlights the need of the development of a gratifications scale exclusively for Facebook. It also emphasizes on a large scale study in Indian context.
\end{abstract}

Keywords: Facebook, gratifications, social networking sites 


\section{Introduction}

Facebook has dominated the social networking world with its growing popularity and rapid growth in terms of its users. Since its inception it has been growing around developed as well as developing countries. It was started as a small application for university students to connect and interact with each other and now it has turned in to the largest and most popular social networking site in the world.

Social networking media has given the internet a new participatory direction by creating the space for user-generated content. Its multifunctional use increases the interpersonal connectivity and hence helps in relationship maintenance (Wellman et al., 2001). Social networking sites such as Facebook provide an inexpensive and easy medium to develop and maintain such interpersonal relationships (Donath \& Boyd, 2004). These sites confer recognition and popularity (Urista, Dong \& Day, 2009) and provide entertainment (Park, Kee \& Valenzuela, 2009). One could claim that social networking sites likefacebook have created a new platform altogether for media users to communicate, many to many. Although recent in origin, social media in general and facebook in particular have engendered good amount of research output (Cha, 2010; Sheldon, 2008; Urista, Dong \& Day, 2009).

The logical question arises is why Facebook is so popular? Why people get attracted towards it? What are the reasons behind their Facebook use? Such questions were raised in the context of other media too such as TV, Newspaper etc. Researchers did adopt Uses and gratifications approach to study such questions in the context of other media. Same approach can be used to understand why people use Facebook. Researchers have already started using it. This article reviews some of the gratification studies conducted in the context of Facebook and tries to understand how researchers have studied the gratifications of Facebook and what are their findings?

\section{Uses and Gratification Theory}

As a sub-tradition of media effects research, Uses and Gratification (U\&G) is one of the most studied and applied theories in the field (McQuail, 1994). Broadly speaking, the theory relates psychological needs to media use (or use of a specific medium) and posits that audiences consciously use a particular medium to seek certain gratifications in order to satisfy their psychological needs (Blumler, 1979; Cantril, 1942; Cha, 2010, Rayburn, 1996; Ruggiero, 
2000). Uses and gratification research began in 1940s when researchers began to investigate why people get engaged in particular media (Wimmer \& Dominick, 1994) and examined their motives for using media such as TV (Rubin, 1981), newspapers, radio and so forth. As part of the growing literature on $U \& G$, it was argued that gratifications vary as per different media (Sherry, Lucas, Greenberg, \& Lachlan, 2006). Going further, researchers then explored the connection between media-use gratifications and audience activity in preexposure time, during the exposure itself, and a post-exposure time of media exposure (Haridakis \& Hanson, 2009; Levy \& Windahl, 1984). While purposive viewers are more intentional in their pre-media exposure planning and are more involved during exposure (Rubin, 2002), motivated viewers are more active during media exposure (Lin, 1993).

Uses and Gratifications framework has been used to examine traditional mass media (such as television) and newly emerging media (such as Internet). Here we examine gratifications derived from Internet because it is inconceivable to think of a social networking site or facebook without the Internet.

\section{Gratifications from Internet}

It has been argued that the gratifications obtained from Internet are different from traditional mass media. This argument mainly rests on the properties of the medium and how they differ from traditional media like newspaper or TV and resemble those of word of mouth (DickenGarcia, 1998; Ruggiero, 2000). The U\&G approach to investigating the Internet has either focused on Internet per se (Krishnatray, Singh, Raghavan, \& Varma, 2009) or its specific uses or applications such as email (Papacharissi \& Rubin, 2000). Either way, the literature shows considerable overlap between gratifications obtained from the medium or its specific uses. Many people use the Internet to socialize with the people (Urista, Dong \& Day, 2009) and seek information, entertainment, interpersonal communication, recognition and relationship maintenance (Matsuba, 2006). Others use internet because of its convenience (Ko, Cho \& Roberts, 2005). Email and chat rooms serve the purpose of interpersonal communication (Papacharissi \& Rubin, 2000). People send messages, share links of their home pages with the people of similar interest and this helps them cultivate relationships (Dominick, 1999). The ease and speed of email and web make users comfortable in making friends with virtual companions (Leighton \& Soulard, 1995). Websites provide information that users seek (Kaye, 
1998). Users can generate their own content and post it on Internet (Song, LaRose, Eastin, \& Lin, 2004).

\section{Cyber Communities}

Although rare, communication researchers have attempted to segment Internet or social networking sites users based on the use of the medium. Coley (2006) refers to the segments as types of cyber communities. He posits that there are three types of cyber communities. The first type indulges in the social networks such as Facebook and MySpace, makes their profiles and uses them to interact with the rest of the cyber social networking world. They primarily use these sites to develop and maintain various kinds of relationships such as professional (LinkedIn.com), academic (thecommunicationspace.com) or romantic (Desktopdating.com). The second type of cyber community gets engaged in to Chat systems. Many sites provide such chat systems, for example - yahoo messenger and Gtalk. The third type of cyber community pertains to the use of blogs, personal websites, news sites and other recommended links. The present study deals with the first kind of cyber community that involves social networking sites such as Facebook. This study tries to review and explain the existing literature around the gratifications of Facebook.

\section{Research Questions}

Specifically, this study responds to following questions:

RQ 1.What was the purpose of these studies?

RQ 2.Who are the target audience of these studies?

RQ 3.What methods are used to study the gratifications?

RQ 4.What are the gratifications factors identified?

RQ 5.How are the gratifications factors operationalized?

\section{Method}

A search was conducted in the databases of EBSCO and Sage to find out the studies that seek to find out gratifications of Facebook use. We could locate total 30 such studies that identified the reasons of using Facebook and other Social Networking Sites. Out of these 30 articles, full texts of the 20 research articles were available to the researchers. Therefore, these 20 research articles were reviewed to seek answers to above research questions. To conduct this review all of the 20 articles were coded in an excel file under variables such as: title, RQs/Hypotheses, 
method used to identify gratifications, gratifications identified, reliability of gratifications factors, and gratifications items contributing to the particular gratifications factor. This summary table was analyzed to respond to the research questions of the present study.

\section{Results}

\section{Purpose of the Study}

Most of these studies were conducted to understand and identify the gratifications of Facebook use. The list of such identified gratifications factors is available in Table $\mathbf{1}$ in Appendix. The studies also attempted to investigate the Facebook use practices of the users. Some of the studies investigated the factors that influence the motives of Facebook use. They also tried to relate gratifications sought and the other constructs. For example - a study (Sarah, 2009) explored the relationship between gratifications and time spent on Facebook. This study found significant evidence of the relationship between these two constructs. Another study by Park, Kee and Valenzuela (2009) explored relationship of demographics and social trust with motivations. A study also investigated the difference between the male and females Facebook users in terms of their motivations of Facebook use (Sheldon, 2008).

\section{Target Audience of the Studies}

Mostly the students were the target audience of these studies. Some of these studies were conducted with the niche audience such as students of a particular university or a group of young adults (Urista, Dong \& Day, 2009).

\section{Methods Used to Study Gratifications}

Several studies conducted to determine gratifications obtained from facebook have relied heavily on the previous literature (Clark, Lee \& Boyer, 2007; Strait, 2008). A trend was evident that most of the studies adapted the gratifications scale from previous literature. The gratification scales used were mostly based on studies conducted on the Internet (Flaherty, Pearce, \& Rubin, 1998; Flanagin \& Metzger, 2001; Papacharissi \& Rubin, 2000). However, some studies adopted the gratifications scales used in traditional media such as television (Barker, 2008). Still other researchers (Foregger, 2009) realized the uniqueness of the application and first conducted in-depth interviews, identified categories of gratifications that were later tested in a large scale survey. Similarly, Urista, Dong and Day (2009) developed 
their gratification scale on the basis of focus group discussions. Few scholars explored other qualitative methods to get themselves to the gratifications factors. Authors of another study asked respondents to respond to an open ended question: why do they use facebook? Answers to this question were analyzed to find out gratifications statements.

\section{Gratifications of Facebook Use}

Most of the studies that investigated the gratifications of facebook use found that people use it to maintain relationships with their facebook friends (Alam, Yeow, \& Loo, 2011; Clark, Lee, \& Boyer, 2007; Urista, Dong \& Day, 2009), entertainment (Sheldon, 2008; Park, Kee, \& Valenzuela, 2009), and pass time (Foregger, 2009; Sheldon \& Gevorgyan, 2008). Some other gratification factors include convenience (Clark, Lee, \& Boyer, 2007), social interaction (Joinson, 2008; Park, Kee, \& Valenzuela, 2009), self-expression (Hanson, Haridakis, Cunningham, Sharma, \& Ponder, 2010; Hou, 2010), virtual community (Sheldon, 2008; Sheldon \& Honeycutt, 2009), popularity (Urista, Dong \& Day, 2009), companionship (Sheldon, \& Gevorgyan, 2008), social information, utilities and upkeep, channel use, market place, maintain/establish old ties, social comparison, sexual attraction and interconnectedness (Foregger, 2009). The user-friendly nature of the platform is also a reason for using facebook (Gadekar, Krishnatray \& Gaur, 2012).

\section{Operationalizing Gratifications}

Users maintain their relationships on facebook through activities such as sending messages to friends, posting on friends wall, staying in touch with friends, getting in touch with new people and contacting people who are hard to reach (Sheldon, 2008). Users get entertainment from facebook as they feel it quite enjoyable and exciting (Barker, 2008). They find it funny (Park, Kee, \& Valenzuela, 2009). They see other people's pictures and read other people's profiles (Sheldon, 2008). People use facebook just to pass their leisure time. They go online on facebook when they get bored. Some do it as a routine thing or habit (Barker, 2008; Sheldon, 2008; Sheldon \& Gevorgyan, 2008). They use facebook just to go away from whatever they are doing right now and got bored with or if they have nothing better to do at that time (Barker, 2008). Convenience is another reason why people use facebook. Facebook is a convenient medium to get the information (Strait, 2008), to get the entertainment (Haridakis \& Hanson, 2009) and to communicate with friends and family members (Clark, Lee, \& Boyer, 2007). The purpose of social interaction includes getting peer support from others, meeting interesting people and talk 
about something with others (Park, Kee, \& Valenzuela, 2009). Researchers also identified that people meet new people and participate in discussions on facebook (Haridakis \& Hanson, 2009).

The gratification of self-expression explains that people use facebook because they can express their opinions freely. They can participate and give their inputs in discussions. They also like to answer to people's questions (Hanson et al., 2010). In her study Sheldon (2008) identified the gratifications of Virtual Community and Companionship. She described the gratification of Virtual community as to make new friends, develop romantic relationship and find more interesting people. She described the gratification of companionship as to get away from loneliness. But in her another study (Sheldon \& Honeycut, 2009) she merged both 'Virtual community' and 'Companionship' under the name of Virtual community. There seems to be an overlap between both the gratifications. Jinghui (2010) stated that people also obtain a gratification of 'Popularity' from playing online games on social networking sites. It resembles to what Park, Kee, \& Valenzuela (2009) have called as 'Self-status seeking'. It states that people use facebook because of peer pressure. It helps them to look cool and also help to develop their career through group participation.

Sarah (2009) identified the gratification of social information that refers to the people's interest in knowing the information about others. The gratification of 'utilities and upkeep' pertains to various activities people do on facebook and seeks updates such as checking messages, updating profiles, posting photos, checking wall comments and photo comments. The gratification of 'Channel use' cites the use of facebook as an alternative communication medium to other means of communication such as email, texting, phone and face to face interaction. The gratification of 'Market place' describes the use of facebook for business purpose such as marketing, selling or buying. Users compare themselves with other facebook users. They maintain their old ties and get inter connected with their friends and family members through facebook. Sarah (2009) also found out that facebook serves people's need of sexual attraction, as when on facebook they look for some attractive profiles of the opposite sex.

There is an overlap among some of the factors identified. Though their labels are different, the variables that contribute to these factors resemble with each other. Sarah (2009) identifies a 
gratification factor called 'Pleasurable way to spend time' which actually a combination of gratification factors of 'time pass' and 'entertainment' that are already identified by other researchers. The variables of a factor called 'Utilities and upkeep' actually resembles with the variables of the factor called 'relationship maintenance'.

\section{Facebook Gratifications Research in the Indian Context}

Our literature search on facebook-related U\&G research shows that studies have been conducted in several parts of the world but there is a scarcity of such studies in Indian context. We could locate only two Indian studies that explored the gratifications Indian Facebook users seek from accessing Facebook.Provided that India is a socially, culturally and geographically different from the world and also diverse within, and that media consumption behaviors differ, it is possible that the gratifications Indian users derive from facebook may be different. But due to unavailability of sufficient evidence in Indian context it is not possible to infer conclusions about the difference between gratifications sought by Indian users and users other than Indians. Following are two Indian study's authors could locate. Gadekar et al. (2011) conducted a study to determine gratifications Indian youth obtain from facebook.. Their analysis yielded five dimensions of gratifications: Relationship maintenance, Entertainment, Relaxation, Social interaction and User-friendliness.

Another study on facebook use amongst Indian teenagers found that school-going boys and girls use facebook to remain in touch with their friends and family and for socializing. Status symbol was the least preferred reason (Maniar \& Deesawala, 2011). One of the limitations of these two studies was the nature of the sample. Gadekar et al's study was limited to the students of a particular educational institute. Maniar and Disawala's study was also limited to a small group. There is a strong need to conduct a large scale study to understand what gratifications Indian users seek from using Facebook.

\section{Discussion}

Most of the studies focused on identifying the gratifications of Facebook. Some of them tried to explore the relationship between gratifications and other constructs. One of them investigated the difference between male and female users. Target audience of these studies was youth, especially students, as they form the major chunk of Facebook use in the world. 
Relationship maintenance, entertainment, time pass and social interaction are some of the prominent gratifications identified in the studies.

It is evident that most of the studies conducted in the context of Facebook gratifications were based mostly on previous literature. They borrowed or adapted existing Internet gratifications scale from previous literature and applied it to conduct their study. Some of the studies used gratifications scale originally used to study the gratifications sought from other media. The medium of Facebook is itself different from other media, even from Internet. Though there are some similarities, Facebook has its own interactive characteristics that make it different from other media. Therefore, the gratifications sought from Facebook use might be different from other media. We feel that there is a strong need to develop a separate scale for Facebook. Series of such studies would be helpful to come up a scale that can be exclusively used to study Facebook gratifications. There is a scarcity of academic studies on Facebook in Indian context. Carrying out such studies in Indian context would help in understanding the motivation of Indian users for using Facebook. It was noticed that there is a bit overlap among some of the gratifications. It happened due to the similarities and differences in the operational definitions of the gratifications factors. Hence, researchers have to be more conscious while labeling or operationalizing the identified gratification factor. 


\section{References}

Alam, S. S., Yeow, P., \& Blumler, J. G. (1979). The role of theory in uses and gratifications studies. Communication Research, 6(1), 9-36.

Cantril, H. (1942). Professor quiz: A gratifications study. In P. F. Lazarsfeld \& F. Stanton (Eds.), Radio research 1941, (pp. 34-45). New York: Duell, Sloan \& Pearce.

Clark, N., Lee, S., \& Boyer, L. (2007).A Place of Their Own: An Exploratory Study of College Students' Uses of Facebook.Conference Papers -- International Communication Association, 2007 Annual Meeting, p1-1, 1p.

Dicken-Garcia, H. (1998). Internet and continuing historical discourse.Journalism and Mass Communication Quarterly, 75, 19-27.

Dominick, J. (1999). Who do you think you are? Personal home pages and self- presentation on the World Wide Web. Journalism and Mass Communication Quarterly, 76(4), 646-658.

Donath, J., \& Boyd, D. (2004). Public displays of connection. BT Technology Journal, 22(4), 71.

Flaherty, L. M., Pearce, K., \& Rubin, R. B. (1998). Internet and face-to-face communication: Not functional alternatives. Communication Quarterly, 46, 250-268.

Flanagin, A. J., \& Metzger, M. J. (2001). Internet use in the contemporary media environment. Human Communication Research, 27, 153-181.

Foregger, S. (2009).The Uses and Gratifications of Facebook.com. Conference Papers -National Communication Association, 2009, p1.

Hanson, G., Haridakis, P. M., Cunningham, A. W., Sharma, R., \& Ponder, J. D. (2010). YouTube. Mass Communication \& Society, 13(5), 584-607. https://doi.org/10.1080/15205436.2010.513470

Haridakis, P., \& Hanson, G. (2009). Social Interaction and Co-Viewing with YouTube: Blending Mass Communication Reception and Social Connection. Journal of Broadcasting \& Electronic Media, 53(2), 317-335. https://doi.org/10.1080/08838150902908270

Hou, J. (2010). Uses and Gratifications of Social Games: Blending Social Networking and Game Play. Conference Papers -- International Communication Association, 2010 Annual Meeting, p1, 0p.

Joinson, N. A. (2008). 'Looking at', 'Looking up' or 'Keeping up with' People? Motives and uses of Facebook. CHI 2008 Proceedings: 1027-1036.

Kaye, B. K. (1998). Uses and gratifications of the World Wide Web: From couch potato to Web potato. The New Jersey Journal of Communication, 6(1), 21-40. 
Ko, H., Cho, C., \& Roberts, M. S. (2005). Internet Usage and Gratifications. Journal of Advertising, 34, 57-70.

Leighton, T., \& Soulard, J. (1995). Electronic confidants. Canadian Geographic, 115(6), 64-67.

Levy, M. R., \& Windahl, S. (1984). Audience activity and gratifications: A conceptual clarification and exploration. Communication Research, 11, 51-78.

Lin, C. A. (1993). Modeling the gratification-seeking process of television viewing. Human Communication Research, 20, 224-244.

Loo, H. S. (2011). An Empirical Study on Online Social Networks Sites Usage: Online Dating Sites Perspective. International Journal of Business and Management, 6(10), 155-161.

Matsuba, K. (2006). Searching for self and relationships online. Cyber Psychology \& Behavior, 9(3), 275-284.

McQuail, D. (1994). The rise of media of mass communication. In D. McQuail (Ed.), Mass communication theory: An introduction (pp. 1-29). London: Sage.

Papacharissi, Z., \& Rubin, A. (2000). Predictors of Internet use. Journal of Broadcasting and Electronic Media, 44, 75-196.

Papacharissi, Z., \& Rubin, A. M. (2000). Predictors of internet use. Journal of Broadcasting \& Electronic Media, 44, 175-196.

Park, N., Kee, K., \& Valenzuela, S. (2009-11-11). Understanding Group Participation in Social Networking Environment: Motivations for Using Facebook Groups and Social Outcomes. Paper presented at the annual meeting of the NCA 95th Annual Convention, Chicago Hilton \& Towers, Chicago, IL Online <PDF>. 2011-06-06 from http://www.allacademic.com/meta/p320401_index.html

Rayburn, J. D. (1996). Uses and gratifications.In Michael B. Salwen and Don W. Stacks (Eds). An integrated approach to communication theory and research. Mahwah, N.J.: Erlbaum, pp. 145-163.

Rubin, A. M. (1981). An Examination of Television Viewing Motives. Communication Research, 8, 141-165.

Rubin, A. M. (2002). The uses-and-gratifications perspective of media effects. In J. Bryant \& D. Zillman (Eds.), Media effects: Advances in theory and research (2nd ed.) (pp. 524548). Mahwah, NJ: Lawrence Erlbaum Associates.

Ruggiero, T. E. (2000). Uses and gratifications theory in the 21 st century. Mass Communication \& Society, 3, 3-37. 
Sheldon, P., \& Gevorgyan, G. (2008). Men are from Mars, Women are from Venus: Gender and Personality Differences Reconfirmed in Virtual Reality. Conference Papers -- National Communication Association, 2008, p1, 25p.

Sheldon, P., \& Honeycutt, J. (2009). Unwillingness to Communicate Impact on Motives for Facebook Use. Conference Papers. International Communication Association, 2009 Annual Meeting, p1-27, 27p.

Sheldon, P. (2008). Student Favorite: Facebook and Motives for its Use. Southwestern Mass Communication Journal, 23(2), 39-53.

Sherry, J. L., Lucas, K., Greenberg, B. S., \& Lachlan, K. (2006). Video game uses and gratifications as predictors of use and game preference. In P. Vorderer\& J. Bryant (Eds.), Playing video games: Motives, responses, consequences (pp. 213-224). Philadelphia: Lawrence Erlbaum Associates.

Song, I., Larose, R., Eastin, M. S., \& Lin, C. A. (2004). Internet gratifications and Internet addiction: On the uses and abuses of new media. Cyberpsychology \& Behavior, 7 , 384393.

Urista, M. A., Dong, Q., \& Day, K. D. (2009). Explaining Why Young Adults Use MySpace and Facebook Through Uses and Gratifications Theory. Human Communication (A Publication of the Pacific and Asian Communication Association), 12(2), 215-229.

Wellman, B. (2001). Physical place and cyber-place: The rise of networked Individualism. International Journal for Urban and Regional Research, 25, 227-252.

Wimmer, R. D., \& Dominick, J. R. (1994). Mass media research: An introduction. Belmont, CA: Wadsworth. 


\section{APPENDIX}

Table 1. List of Facebook Gratification studies and gratifications factors

\begin{tabular}{|c|c|c|c|c|}
\hline Sr No & Author & Title of the study & Gratification factors & Reliability \\
\hline \multirow[t]{2}{*}{1} & $\begin{array}{l}\text { Pavica Sheldon \& } \\
\text { James M. Honeycutt }\end{array}$ & $\begin{array}{l}\text { Unwillingness to } \\
\text { communicate impact on the } \\
\text { motives for Facebook use }\end{array}$ & Passing Time & .84 \\
\hline & & & Virtual Community & .80 \\
\hline 2 & Sonia Livingstone & & No specific factors & $\begin{array}{l}\text { Qualitative } \\
\text { study }\end{array}$ \\
\hline 3 & $\begin{array}{l}\text { Bernhard Debatin, } \\
\text { Jennette P Lovejoy, } \\
\text { Ann-Kathrin Horn } \\
\text { and Brittany N. } \\
\text { Hughes }\end{array}$ & $\begin{array}{l}\text { Facebook and } \\
\text { online privacy: } \\
\text { Attitudes, } \\
\text { behaviors, and unintended } \\
\text { consequences }\end{array}$ & Perceived benefits & \\
\hline 4 & $\begin{array}{l}\text { Clark, Naeemah; Lee, } \\
\text { Shu-Yueh; } \\
\text { Boyer, Lori, } 2007\end{array}$ & $\begin{array}{l}\text { A place of their own: An } \\
\text { exploratory study of college } \\
\text { students uses of Facebook }\end{array}$ & $\begin{array}{l}\text { Interpersonal utility, pass time, } \\
\text { information seeking, } \\
\text { convenience and entertainment }\end{array}$ & \\
\hline 5 & $\begin{array}{l}\text { Mark Urista, } \\
\text { Qingwen Dong and } \\
\text { Kenneth D. Day }\end{array}$ & $\begin{array}{l}\text { Explaining why young } \\
\text { adults use MySpace and } \\
\text { Facebook through uses and } \\
\text { gratifications theory }\end{array}$ & $\begin{array}{l}\text { Efficient communication, } \\
\text { Convenient communication, } \\
\text { Curiosity about others, } \\
\text { Popularity, Relationship } \\
\text { formation and reinforcement. }\end{array}$ & $\begin{array}{l}\text { Qualitative } \\
\text { method } \\
\text { Focus group } \\
\text { discussion }\end{array}$ \\
\hline \multirow[t]{6}{*}{6} & Pavica Sheldon & $\begin{array}{l}\text { Students Favorite: } \\
\text { Facebook and Motives for its } \\
\text { Use }\end{array}$ & Relationship maintenance, & .90 \\
\hline & & & passing time, & .83 \\
\hline & & & virtual community, & .80 \\
\hline & & & entertainment, & .84 \\
\hline & & & coolness, & .76 \\
\hline & & & companionship & \\
\hline \multirow[t]{2}{*}{7} & $\begin{array}{l}\text { Park, N. , Kee, K. and } \\
\text { Valenzuela, S. , } \\
2009\end{array}$ & $\begin{array}{l}\text { Understanding } \\
\text { participation in Social } \\
\text { Networking Environment: } \\
\text { Motivations for using } \\
\text { Facebook groups and social } \\
\text { outcomes }\end{array}$ & Social interaction & .67 \\
\hline & & & Entertainment & .72 \\
\hline
\end{tabular}


Online Journal of Communication and Media Technologies

Volume: 7 - Issue: 1 January - 2017

\begin{tabular}{|c|c|c|c|c|}
\hline Sr No & Author & Title of the study & Gratification factors & Reliability \\
\hline & & & Self-status seeking & .81 \\
\hline & & & Information seeking & .76 \\
\hline 8 & Hou, Jinghui & $\begin{array}{l}\text { Uses and Gratifications of } \\
\text { Social Games: Blending } \\
\text { Social Networking and } \\
\text { Game Play }\end{array}$ & $\begin{array}{l}\text { Expected Social gratifications: } \\
\text { social connections, social } \\
\text { investigation, shared identity, } \\
\text { popularity, and self-expression. } \\
\text { Game gratifications: competition, } \\
\text { challenge, } \\
\text { diversion, fantasy and arousal } \\
\end{array}$ & \\
\hline \multirow[t]{9}{*}{9} & Foregger, Sarah. & $\begin{array}{l}\text { The Uses and Gratifications } \\
\text { of Facebook.com }\end{array}$ & Pleasurable way to spend time & .917 \\
\hline & & & Utilities and upkeep & .871 \\
\hline & & & Channel use & .833 \\
\hline & & & Maintain/establish old ties & .858 \\
\hline & & & Interconnectedness & .853 \\
\hline & & & Social comparison & .863 \\
\hline & & & Market place & .828 \\
\hline & & & Social information & .834 \\
\hline & & & Sexual attraction & .898 \\
\hline 10 & $\begin{array}{l}\text { Alam, Syed Shah; } \\
\text { Yeow, Paul H P; } \\
\text { Loo, H S. }\end{array}$ & $\begin{array}{l}\text { An Empirical Study on } \\
\text { Online Social Networks } \\
\text { Sites Usage: Online Dating } \\
\text { Sites Perspective }\end{array}$ & $\begin{array}{l}\text { Reasons of using online social } \\
\text { networks: facilitate social } \\
\text { relationships, Entertainment }\end{array}$ & \\
\hline \multirow[t]{5}{*}{11} & $\begin{array}{l}\text { Sheldon, Pavica; } \\
\text { Gevorgyan, Gennadi. }\end{array}$ & $\begin{array}{l}\text { Men are from Mars, Women } \\
\text { are from Venus: Gender and } \\
\text { Personality Differences } \\
\text { Reconfirmed in } \\
\text { Virtual Reality } \\
\end{array}$ & $\begin{array}{l}\text { Relationship Maintenance }(\mathrm{V}= \\
31.11)\end{array}$ & .90 \\
\hline & & & Passing Time $(\mathrm{V}=9.66)$ & .82 \\
\hline & & & Entertainment $(\mathrm{V}=4.84)$ & .78 \\
\hline & & & Virtual community $(\mathrm{V}=4.1)$ & .77 \\
\hline & & & Companionship $(\mathrm{V}=3.53)$ & .71 \\
\hline
\end{tabular}


Online Journal of Communication and Media Technologies

Volume: 7 - Issue: 1 January - 2017

\begin{tabular}{|c|c|c|c|c|}
\hline Sr No & Author & Title of the study & Gratification factors & Reliability \\
\hline \multirow[t]{4}{*}{12} & Barker, Valerie. & $\begin{array}{l}\text { Older Adolescents' } \\
\text { Motivations for Use of } \\
\text { Social Networking Sites: } \\
\text { The Influence of Group } \\
\text { Identity and Collective } \\
\text { Self-esteem }\end{array}$ & Social identity gratification & .93 \\
\hline & & & Companionship & .88 \\
\hline & & & Pass Time & .87 \\
\hline & & & Entertainment & .85 \\
\hline \multirow[t]{6}{*}{13} & $\begin{array}{l}\text { Hanson, Gary; } \\
\text { Haridakis, Paul } \\
\text { Michael; } \\
\text { Cunningham, } \\
\text { Audrey Wagstaff; } \\
\text { Sharma, Rekha; } \\
\text { Ponder, J. D. }\end{array}$ & $\begin{array}{l}\text { The } 2008 \text { Presidential } \\
\text { Campaign: } \\
\text { Cynicism in the Age of } \\
\text { Facebook, MySpace, and } \\
\text { YouTube }\end{array}$ & Political evaluation, & .93 \\
\hline & & & Convenient information seeking, & .90 \\
\hline & & & Entertaining arousal, , & .91 \\
\hline & & & Gainful companionship & .82 \\
\hline & & & Self-expression, & .81 \\
\hline & & & Pass time & .86 \\
\hline \multirow[t]{6}{*}{14} & $\begin{array}{l}\text { Haridakis, Paul; } \\
\text { Hanson, Gary }\end{array}$ & $\begin{array}{l}\text { Social Interaction and } \\
\text { CoViewing With YouTube: } \\
\text { Blending Mass } \\
\text { Communication Reception } \\
\text { and Social Connection }\end{array}$ & Convenient Entertainment, & .95 \\
\hline & & & Interpersonal connections, & .92 \\
\hline & & & Convenient information seeking, & .84 \\
\hline & & & Escape, & .77 \\
\hline & & & Co-viewing, & .78 \\
\hline & & & Social interaction & .43 \\
\hline \multirow[t]{2}{*}{15} & Strait, Laurance & $\begin{array}{l}\text { The Effect of Political } \\
\text { Efficacy on Web } 2.0 \\
\text { Usage: The } 2008 \text { Primaries. }\end{array}$ & Convenience, & .816 \\
\hline & & & Social utility & .840 \\
\hline
\end{tabular}




\begin{tabular}{|c|c|c|c|c|}
\hline Sr No & Author & Title of the study & Gratification factors & Reliability \\
\hline & & & Entertainment, & .797 \\
\hline & & & Guidance & .802 \\
\hline \multirow[t]{7}{*}{16} & Adam N. Joinson & $\begin{array}{l}\text { 'Looking at', 'Looking up' } \\
\text { or 'Keeping up with' } \\
\text { People- Motives and Uses } \\
\text { of Facebook }\end{array}$ & Social connection & .89 \\
\hline & & & Shared identities & .74 \\
\hline & & & Photographs & .89 \\
\hline & & & Content & .74 \\
\hline & & & Social investigation & .75 \\
\hline & & & Social network surfing & .79 \\
\hline & & & Status updates & .71 \\
\hline 17 & $\begin{array}{l}\text { Jang Hyun Kim, Min- } \\
\text { Sun Kim, and } \\
\text { Yoonjae Nam }\end{array}$ & $\begin{array}{l}\text { An Analysis of } \\
\text { SelfConstruals, } \\
\text { Motivations, Facebook Use, } \\
\text { and User } \\
\text { Satisfaction }\end{array}$ & $\begin{array}{l}\text { All } 21 \text { items were classified in to } \\
\text { two groups: social and nonsocial } \\
\text { motivations }\end{array}$ & \\
\hline \multirow[t]{5}{*}{18} & $\begin{array}{l}\text { Yong GuJi, Hwan } \\
\text { Hwangbo, JiSoo Yi, } \\
\text { P. L. Patrick Rau, } \\
\text { Xiaowen Fang, and } \\
\text { Chen Ling }\end{array}$ & $\begin{array}{l}\text { The Influence of Cultural } \\
\text { Differences on the Use of } \\
\text { Social Network Services } \\
\text { and the Formation of Social } \\
\text { Capital }\end{array}$ & Expert search & $\begin{array}{l}\text { Total } \\
\text { reliability of } \\
18 \text { items: } \\
.941\end{array}$ \\
\hline & & & Communication & \\
\hline & & & Connection & \\
\hline & & & Content sharing & \\
\hline & & & Identity & \\
\hline \multirow[t]{4}{*}{19} & $\begin{array}{l}\text { Daniël G. Muntinga, } \\
\text { Marjolein Moorman } \\
\text { and Edith G. Smit }\end{array}$ & $\begin{array}{l}\text { Introducing COBRAs } \\
\text { Exploring motivations for } \\
\text { brand-related social media } \\
\text { use }\end{array}$ & Information & \\
\hline & & & Personal Identity & \\
\hline & & & Integration and social interaction & \\
\hline & & & Entertainment & \\
\hline \multirow[t]{2}{*}{20} & $\begin{array}{l}\text { Gadekar R, } \\
\text { Krishnatray P and } \\
\text { Gaur S (2012) } \\
\end{array}$ & $\begin{array}{l}\text { A descriptive study of } \\
\text { facebook uses amongst } \\
\text { Indian students } \\
\end{array}$ & Relationship Maintenance & \\
\hline & & & User-friendliness & \\
\hline
\end{tabular}


Online Journal of Communication and Media Technologies

Volume: 7 - Issue: 1 January - 2017

\begin{tabular}{|l|l|l|l|l|}
\hline Sr No & Author & Title of the study & Gratification factors & Reliability \\
\hline & & & Relaxation & \\
\hline & & & Connecting with old friends & \\
\hline & & & Social interaction & \\
\hline
\end{tabular}

